\title{
PENDIDIKAN HUMANIS RELIGIUS BERBASIS KULTUR DI MADRASAH ALIYAH NEGERI 2 PEKALONGAN
}

\author{
Fajar Dadari, Ajat Sudrajat \\ fajardadari@gmail.com dan ajat@uny.ac.id \\ Universitas Negeri Yogyakarta
}

\begin{abstract}
Abstrak
Penelitian ini bertujuan untuk menemukan pendidikan humanis religius berbasis kultur di Madrasah Aliyah Negeri 2 Pekalongan. Pendekatan penelitian yang digunakan dalam penelitian ini adalah pendekatan kualitatif. Sampel sumber data diperoleh dengan purposive sampling. Pengumpulan data dengan teknik pengamatan, wawancara mendalam (in-depth interview), catatan lapangan, dan penggunaan studi dokumen; sedangkan uji keabsahan data dengan metode triangulasi. Analisis data bersifat induktif/kualitatif dengan metode Miles and Huberman. Hasil penelitian adalah sebagai berikut: (1) Perilaku siswa sebelum dilakukan perbaikan kultur madrasah adalah: (a) aktualisasi nilai humanis religius para siswa di Madrasah Aliyah Negeri 2 Pekalongan kurang sempurna, (b) Pendidikan yang memberikan kebebasan siswa dalam beraktualisasi diri, sikap peserta didik menjadi lebih "terbuka" dan dekat dengan pendidik, kreatif serta berprestasi dalam bidang yang ditekuni; (2) Karakteristik nilai religius siswa tidak utuh; (3) Pendidikan nilai humanis religius berbasis kultur madarasah ini dilakukan dengan beberapa tahap: (a) menggambarkan kultur madrasah, yang meliputi material culture dan behavioral culture, yang pada akhirnya ditemukan kultur positif dan negatif; (b) menentukan visi dan misi madrasah, (c) pendidikan nilai humanis religius dirancang dan dilaksanakan melalui saluran kultur madrasah.

Kata kunci: pendidikan humanis religius, kultur madrasah.
\end{abstract}

\section{A CULTURE-BASED HUMANISTIC RELIGIOUS EDUCATION AT MADRASAH ALIYAH NEGERI 2 PEKALONGAN}

Fajar Dadari, Ajat Sudrajat

fajardadari@gmail.com dan ajat@uny.ac.id

Universitas Negeri Yogyakarta

\begin{abstract}
This study aims to reveal a culture-based humanistic religious education at Madrasah Aliyah Negeri 2 Pekalongan. The study employed the qualitative approach. The sample of the data sources was selected by means of the purposive sampling technique. The data were collected through observations, in-depth interviews, field notes, and documentation, and the trustworthiness was enhanced through data triangulation. The data analysis was inductivelqualitative and the data analysis process employed the method by Miles and Huberman. The research activities included portraying the culture of Madrasah Aliyah Negeri 2 Pekalongan, and analyzing and revealing meanings. The research findings are as follows. (1) The students' behaviors after the improvement or betterment of the madrasah culture include the following. (a)The actualization of the students' humanistic religious values in education at Madrasah Aliyah Negeri 2 Pekalongan is not perfect, (b) An education that gives the students freedom for self-actualization makes them more open and close to the teachers, creative, and have achievements in the fields of their interest. (2) The characteristics of the students' religious values are not holistic (3) The humanistic religious value education based on the madrasah culture is implemented through several stages as follows: (a) portraying the madrasah culture, comprising the material and behavioral cultures, and finally finding out the positive and negative cultures; (b) setting the madrasah vision and mission; and (c) designing humanistic religious value education and implementing it through the madrasah culture as a channel.
\end{abstract}

Keywords: humanistic religious education, madrasah culture. 


\section{Pendahuluan}

Tatanan kehidupan manusia sudah mengalami perubahan yang mendasar karena hancurnya rasa kemanusiaan dan terkikisnya semangat religius, serta kaburnya nilai-nilai kemanusiaan dan hilangnya jati diri budaya bangsa merupakan kekhawatiran manusia paling klimaks (memuncak) dalam kancah pergulatan global. Generasi kita saat ini lebih bangga dengan budaya orang lain daripada budaya sendiri. Hal yang perlu diwaspadai adalah budaya yang bersifat negatif (Arief dkk, 2011, p.17).

Fenomena yang muncul di manamana saat ini adalah menurunnya rasa hormat anak terhadap orang tuanya dan menurunnya rasa hormat peserta didik terhadap guru-gurunya. Di masyarakat ditemukan banyak terjadi kerusuhan, pelecehan terhadap orang lain, kekerasan, bahkan pembunuhan dan kejahatan-kejahatan yang lainnya yang terjadi bukan perilaku berbudaya dan manusiawi, tetapi perilaku yang kurang bahkan tidak beradab dan tidak manusiawi. Melihat fenomena seperti ini, wajar jika sebagian masyarakat bersikap pesimis dan meragukan kemampuan lembaga pendidikan untuk melaksanakan fungsinya dengan baik (Dardiri, 2010, p.7).

Pendidikan humanis religius dapat membentuk karakter peserta didik menjadi manusia yang "berperikemanusiaan" dan akan menghasilkan pribadi-pribadi utuh seperti berikut: (a) pribadi-pribadi yang tinggi secara intelektual, gemar beramal, dan anggun dalam bermoral sebagai perwujudan dari potensi kodrati yang dimilikinya; (b) pribadi-pribadi yang memahami hakikat dirinya; (c) pribadipribadi yang memahami tugas serta tanggung jawabnya sebagai hamba dan khalifah Allah di alam semesta; (d) pribadi-pribadi yang menghargai dirinya sendiri sebagai manusia; (e) pribadi-pribadi yang menghargai manusia lain seperti halnya dia menghargai dirinya sendiri; (f) pribadi-pribadi yang memahami dan bersedia melaksanakan kewajiban serta hak-haknya sebagai manusia; (g) pribadi-pribadi yang mampu memanfaatkan seluruh potensi dirinya sesuai dengan kemampuan yang dimilikinya. (h). Pribadi-pribadi yang menyadari adanya kekuatan akhir yang mengatur seluruh hidup manusia (Al-Fandi, 2011, pp. 196-197).
Orientasi religius bermaksud melahirkan insan pendidikan yang dapat melaksanakan relasi vertikal dengan Allah (habl minallah) dalam posisinya sebagai 'abd Allah, dan melahirkan insan pendidikan yang mampu mengadakan hubungan horizontal dengan sesama manusia (habl minannas), serta dengan sesama makhluknya secara seimbang. Sebagai 'abd Allah, siswa harus mampu menjalankan tugas dan kewajibannya dengan baik dan benar, dan tidak tercabut dari kebenaran faktualnya bahwa siswa merupakan bagian dari masyarakat dalam dimensi sosiologisnya. Jadi, siswa harus menunjukkan kesalehan sosialnya (Arief dkk, 2011, pp. 145-146).

Pendidikan humanis religius berfungsi sebagai sarana pembentukan manusia paripurna, atau dalam terminologi kependidikan Islam disebut dengan muslim paripurna atau insan kamil. Paradigma pendidikan humais religius memandang manusia dalam kerangka holistik. Kegiatan pendidikan humanis religius tidak hanya kognitif saja, namun lebih dari itu, ada nilai-nilai lain yang ingin diraih. Demi kehidupan kemanusiaan yang substantif, pendidikan humanis religius melakukan proses pengisian kalbu sebagai upaya memperteguh potensi iman. Ajaran Islam yang utuh meliputi akidah (keimanan), syariah (ibadah dan muamalah), dan akhlak (budi pekerti). Dengan keimanan yang benar, akan memimpin manusia ke arah budi pekerti yang luhur dan berakhlak mulia. Dengan akhlak yang mulia, akan membawa ke arah usaha memahami hakikat dan mengaplikasikan ilmunya secara benar. Dengan ilmu yang benar akan membawa manusia kepada amal saleh (Arief dkk, 2011, pp. 147-148).

Menurut Fangerlind \& Saha (Dardiri, 2010, p. 18), sekurang-kurangnya ada dua alasan mengapa pendidikan humanis religius itu perlu diwujudkan. Alasan Pertama, masyarakat Indonesia sekarang sedang dihadapkan pada adanya kenyataan bahwa perilaku masyarakat Indonesia yang merupakan hasil dari pendidikan di Indonesia selama ini, menunjukkan tanda-tanda semakin jauh dari nilainilai budaya Indonesia (Pancasila). Alasan Kedua, dasar filosofis pendidikan nasional di Indonesia yakni Pancasila yang humanis religius atau humanis theologis belum mewarnai praktek pendidikan di Indonesia. 


\section{Metode Penelitian}

Berdasarkan permasalahan yang diajukan dalam penelitian ini, yang lebih mengutamakan pada masalah proses dan makna atau persepsi, maka penelitian ini menggunakan jenis penelitian deskriptif kualitatif. Deskriptif kualitatif adalah mendeskripsikan segala situasi atau area populasi tertentu yang bersifat faktual secara sistematis dan akurat. Penelitian deskriptif kualitatif dapat diartikan pula sebagai penelitian untuk memotret fenomena individual, situasi kelompok tertentu yang berlangsung secara kekinian (Sudarwan, 2002, p. 41).

Untuk memperoleh informasi mengenai fokus penelitian ini, maka peneliti menggunakan teknik purposive sampling yaitu pengambilan sampel berdasarkan pada wilayah penelitian dengan subjek penelitian ditentukan atas tujuan tertentu (Usman, dkk, 2011, pp. 45-47). Subjek penelitian yang ditentukan tersebut berdasarkan kriteria-kriteria tertentu guna mendapatkan data atau informasi dari objek tersebut yang sesuai dengan keperluan.

Subjek Penelitian.

Sampel dalam penelitian kualitatif, dapat menjadi informan (jika menggunakan wawancara), dapat berupa kejadian (jika menggunakan observasi), jika menggunakan teknik dokumentasi, maka sampel dapat berupa bahan-bahan dokumenter, prasasti, legenda, cerita rakyat dan sebagainya (Bungin, 2012, pp. 84-101). Subjek penelitian dalam penelitian ini adalah MAN 2 Pekalongan. Informan pada subjek penelitian yang dipilih mampu memberikan informasi yang cukup untuk penelitian ini.

\section{Objek Penelitian}

Objek penelitian ini adalah: karakteristik nilai humanis religius para siswa Madrasah Aliyah Negeri 2 Pekalongan, pendidikan humanis religius yang diterapkan dalam pendidikan di Madrasah Aliyah Negeri 2 Pekalongan, pendidikan yang efektif, yang diterapkan dalam pendidikan nilai humanis religius pada diri siswa berbasis kultur Madrasah di MAN 2 Pekalongan.

\section{Teknik Pengumpulan Data}

Pengumpulan data dalam penelitian ini menggunakan tiga teknik, yaitu:

\section{Pengamatan (Observasi)}

Observasi dalam penelitian yaitu pengamatan langsung secara mendalam dengan menggunakan instrumen pengamatan dan tidak mengajukan pertanyaan-pertanyaan. Selain itu observasi juga merupakan pengamatan secara langsung terhadap suatu fenomena yang dikaji dan menangkap kehidupan budaya dari segi pandangan peneliti pada keadaan waktu itu (Moleong, LJ 2013, pp. 174-175).

\section{Wawancara}

Wawancara adalah percakapan dengan maksud tertentu, dan dilakukan oleh dua pihak yaitu pewawancara (interviewer) yang mengajukan pertanyaan dan yang diwawancarai (interviewee) yang memberikan jawaban atas pertanyaan itu. Dalam penelitian ini peneliti menggunakan dua teknik wawancara, yaitu terstruktur dan tidak terstruktur (Moleong, LJ, 2013, pp. 134-136).

\section{Dokumentasi}

Metode dokumentasi adalah mencari data mengenai hal-hal atau variabel berupa catatan, transkrip, buku, surat kabar, majalah dan sebagainya. Teknik dokumentasi ini digunakan untuk mengumpulkan data yang berkaitan dengan penelitian. Dokumentasi dalam penelitian ini yaitu dengan mempelajari dokumen yang berkaitan dengan pola pendidikan humanis religius berbasis kultur di MAN 2 Pekalongan, khususnya yang berkaitan dengan pola pendidikan humanis religius. Hal itu dilakukan untuk memperoleh data-data dengan membaca, dan menggunakan bukubuku yang berkaitan dengan masalah yang akan di teliti.

\section{Instrumen Pengumpulan Data}

Instrumen penelitian pengumpulan data dalam penelitian kualitatif adalah peneliti itu sendiri, jadi dapat dikatakan peneliti sebagai instrumen penelitian. Kedudukan peneliti dalam penelitian kualitatif cukup rumit. Peneliti sekaligus merupakan perencana, pelaksana pengumpulan data, analisis, penafsir data, dan pada akhirnya peneliti menjadi pelapor hasil penelitian. Pengertian instrumen atau alat ukur dalam penelitian di sini tepat, karena peneliti menjadi segalanya dari keseluruhan proses penelitian. Instrumen penelitian di sini dimak- 
sudkan sebagai alat pengumpulan data (Moleong, LJ, 2013, p.168).

Peneliti harus terjun sendiri ke lapangan untuk pengumpulan data, mulai dari observasi, wawancara maupun dokumentasi. Peneliti sebagai instrumen pengumpul data merupakan prinsip utama dalam penelitian kualitatif.

Sumber

Penelitian ini tentu tidak akan lepas dari sumber tertulis yang diperoleh dari berbagai buku-buku yang relevan. Kemudian dari media cetak dan internet atau media elektronik yang terkait dengan judul penelitian, serta hasil dari wawancara dengan kepala sekolah dan guru yang terkait dengan pendidikan humanis religius berbasis kultur di MAN 2 Pekalongan.

Menurut Lofland dan Lofland, sumber data yang utama dalam penelitian kualitatif adalah kata-kata dan tindakan selebihnya adalah data tambahan seperti dokuman dan literatur lain. Data yang paling penting untuk dikumpulkan dan dikaji dalam penelitian ini adalah data kualitatif (Moleong, LJ, 2013, p. 157).

Kata-kata dan tindakan orang-orang yang diamati atau diwawancarai merupakan sumber data yang utama. Pencatatan sumber data utama melalui wawancara dan pengamatan berperan serta merupakan hasil usaha gabungan dari kegiatan melihat, mendengar, dan bertanya. Selain itu adalah data tambahan atau data sekunder seperti dokumen, media cetak, media elektronik (internet), data hasil studi pustaka lainnya. Data yang disajikan berupa tulisan deskriptif analisis hasil wawancara dan sumber lainnya.

Jenis sumber data yang digunakan dalam penelitian ini meliputi hal-hal sebagai berikut:

\section{Data tidak tertulis}

Narasumber atau informan yang terdiri dari pihak-pihak perorangan maupun instansi (lembaga) yang terkait dalam penelitian ini. 2) Tempat dan aktivitas yaitu tempat pendidikan nilai humanis religius dilaksanakan. 3) Dokumentasi foto-foto.

\section{Data tertulis}

Penulisan ini tentu tidak lepas dari sumber tertulis yang diperoleh dari buku-buku yang relevan, media cetak, internet, radio, dan media elektronik yang terkait dengan judul penelitian. Dari sumber-sumber yang tertera di atas maka akan menghasilkan data. Data yang disajikan berupa tulisan deskriptif analisis hasil dari wawancara dan sumber lainnya dengan hasil ketikan dari komputer dan hasil berupa laporan. Sumber data penelitian ini terdapat dua informan, yaitu key informan (informan kunci) dan informan pendukung. Informan ditunjuk sebagai sumber data yang mampu memberikan informasi selengkaplengkapnya serta relevan terhadap tujuan penelitian.

Informan kunci dalam penelitian ini adalah kepala sekolah dan guru di MAN 2 Pekalongan yang berperan penting dalam pendidikan humanis religius berbasis kultur di MAN 2 Pekalongan, sedangkan informan pendukung adalah siswa. Selain itu, didukung juga dengan sumber tertulis dari buku-buku yang relevan, internet, media cetak, dan lain sebagainya.

\section{Jenis Data}

Data yang disajikan berupa analisis deskriptif yang merupakan hasil dari observasi, wawancara, dokumen pribadi maupun dokumen resmi, serta sumber lain yang menunjang. Kemudian hasilnya berupa laporan penelitian.

Validitas sering disebut juga dengan keabsahan. Keabsahan dalam penelitian sering dikaitkan dengan instrumen atau alat ukur. Suatu alat ukur dikatakan valid atau mempunyai nilai validitas yang tinggi apabila alat ukur tersebut mampu mengukur apa yang hendak di ukur. Suatu validitas data sangat diperlukan dalam suatu penelitian, karena validitas data juga merupakan ukuran mutu suatu penelitian. Suatu penelitian tidak akan mempunyai arti apa-apa jika alat ukurnya tidak valid, karena alat ukur tersebut mungkin akan mengumpulkan data yang berbeda dengan apa yang di kehendaki (Nawawi, 2012, pp. 145-148).

Sebuah instrumen dapat dikatakan valid apabila dapat mengungkap data dari variabel yang diteliti secara tepat. Untuk mendapatkan validitas data peneliti menggunakan triangulasi. Triangulasi adalah teknik pemeriksaan keabsahan data yang memanfaatkan sesuatu yang lain di luar data untuk keperluan pengecekan atau sebagai pembanding. Tri- 
angulasi ini menggunakan sumber yang berarti membandingkan maupun mengecek balik derajat kepercayaan suatu informasi yang diperoleh melalui waktu dan alat yang berada dalam metode penelitian kualitatif. Hal tersebut dapat dicapai dengan; (1) membandingkan data hasil pengamatan dengan data hasil wawancara; (2) embandingkan apa yang dikatakan orang di depan umum dengan apa yang dikatakan secara pribadi; (3) membandingkannya dengan apa yang dikatakannya sepanjang waktu; (4) membandingkan keadaan dan perspektif seseorang dengan berbagai pendapat dan pandangan; (5) membandingkan hasil wawancara dengan isi suatu dokumen yang berkaitan.

\section{Teknik Analisis Data}

Penelitian ini menggunakan analisis data kualitatif deskriptif, yang merupakan penggambaran keadaan atau fenomena yang diperoleh kemudian menganalisisnya dengan bentuk kata untuk diperoleh suatu kesimpulan. Data yang telah diperoleh peneliti dalam lapangan kemudian diproses dan diolah sehingga didapatkan kesimpulan dari hasil penelitian.

Proses analisa data menurut Miles dan Huberman (1992, pp.15-21) dilakukan dalam 4 tahap, yaitu:

\section{Pengumpulan Data}

Data yang diperoleh dari hasil observasi, wawancara dan dokumentasi dicatat dalam catatan lapangan yang berisi tentang apa yang di lihat, didengar, dirasakan, disaksikan, dialami dan juga temuan tentang apa yang dijumpai selama penelitian dan hal itu merupakan bahan rencana pengumpulan data untuk tahap berikutnya. Pertama-tama dengan menggali data dari berbagai sumber, yaitu dengan wawancara, pengamatan yang kemudian dituliskan dalam catatan lapangan dengan memanfaatkan dokumen pribadi, dokumen resmi, gambar, foto dan sebagainya. Pengumpulan data dilakukan dengan tiga metode, yaitu observasi, wawancara dan dokumentasi.

\section{Reduksi Data}

Reduksi data adalah bentuk analisis yang menggolongkan, menterjemahkan, membuang yang tidak perlu, serta mengorganisir data sedemikian rupa sehingga dapat ditarik suatu kesimpulan. Reduksi data diartikan sebagai proses di mana peneliti melakukan pemilihan, pemusatan perhatian pada penyederhanaan pengabstrakan dan transformasi data "kasar" dari catatan tertulis di lapangan (Miles \& Huberman, 1992, p. 16).

\section{Penarikan Kesimpulan}

Penarikan kesimpulan menyangkut intepretasi peneliti, yaitu penggambaran makna dari data yang ditampilkan. Peneliti berupaya mencari makna dari data yang telah dihasilkan dalam penelitian, serta menganalisa data dan kemudian membuat kesimpulan. Sebelum menarik kesimpulan, peneliti harus mencari pola, hubungan, persamaaan dan sebagainya antardetail untuk kemudian dipelajari dan kemudian baru disimpulkan. Proses penyimpulan data merupakan suatu proses yang membutuhkan suatu pertimbangan yang benar-benar dapat dipertanggungjawabkan.

Teknik analisis data dalam penelitian ini menggunakan empat tahap seperti yang telah dijelaskan di atas. Kemudian untuk penggambarannya dalam pengumpulan data, penulis mencari data dengan metode observasi, wawancara maupun dokumentasi. Setelah data-data diperoleh penulis melanjutkan tahap berikutnya yaitu mereduksi data. Mereduksi adalah melakukan pemilihan data atau penyederhanaan data, agar hasilnya dapat mempermudah peneliti untuk mencari kembali data yang diperlukan nantinya. Setelah data yang diperoleh direduksi maka data tersebut kemudian disajikan untuk mempermudah peneliti dalam melihat hasil penelitian. Setelah itu yang terakhir penarikan kesimpulan.

Setelah data-data terkumpul, dianalisis dan diorganisir, disajikan kemudian ditarik kesimpulan sebagai jawaban atas setiap permasalahan yang ada. Pengumpulan data, reduksi data, penyajian data, dan penarikan kesimpulan ini merupakan empat langkah kegiatan analisis data proses siklus interktif.

\section{Hasil Penelitian dan Pembahasan}

\section{Gambaran Kultur Madrasah Aliyah Negeri 2} Pekalongan

Pelaksanaan pendidikan humanis religius memanfaatkan pembelajaran di kelas melalui guru-guru mata pelajaran dan kegiatan temporer, seperti pesantren kilat pada bulan 
Ramadhan, maulid nabi dan rajaban. Pendidikan humanis religius dilaksanakan dengan membuat program, shalat berjamaah, dan diisi ceramah singkat.

Gambaran kultur madrasah, meliputi dua aspek pokok, yakni aspek artifak (material culture) dan aspek aktivitas kultur (behavioral culture). Aktivitas kultur (behavioral culture), yang meliputi: (a) fenomena kedisiplinan secara kultural, yang semestinya bisa membentuk nilai kedisiplinan siswa; (b) fenomena kebersihan secara kultural, yang semestinya bisa membentuk budaya bersih bagi siswa; (c) fenomena hubungan antarwarga sekolah, baik dalam kegiatan intrakurikuler maupun ekstrakurikuler, yang bisa menumbuhkan nilai kebebasan berkembang dan kreativitas; (d) kegiatan-kegiatan yang sengaja diadakan di sekolah dengan pola tertentu, sehingga bisa membangun tanggung jawab berdasar normanorma serta kejujuran, sekaligus penanganan kasus-kasus dalam bidang BK untuk membangun karakter siswa; (e) pola pendidikan agama yang dibangun, sehingga bisa menumbuhkan keberagaman secara utuh.

Fenomena karakteristik nilai humanis religius siswa yang merupakan bagian dari hasil pendidikan sekolah, tanpa mengesampingkan pengaruh lingkungan keluarga dan teman pergaulan, akan digunakan untuk membangun pendidikan nilai melalui saluran kultur yang efektif (MF, tanggal 3 Februari 2014).

\section{Karakteristik Nilai Humanis Religius Siswa}

Dampak keagamaan dalam penelitian ini dibatasi dalam bidang nilai-nilai kemanusiaan dan religius, dalam hal ini lebih khusus lagi di bidang karakter nilai humanis religius siswa di madrasah, yang meliputi: nilai kebebasan, bertanggung jawab, kejujuran, kedisiplinan, rasa aman, kreativitas, dan nilai kerja sama. Aspek keberagaman lebih difokuskan pada shalat wajib siswa, mengingat aspek ritual shalat wajib 5 waktu mengandung lima dimensi keberagaman (iman, ilmu, ritual, penghayatan, dampak keagamaan). Pada dimensi dampak keagamaan, terkandung aspek kehidupan lain, yang dalam hal ini dibatasi nilai humanis religius. Pengaruh lingkungan madrasah yang berbeda-beda karakteristiknya telah membentuk karakteristik keagamaan siswa yang berbeda pula. Siswa-siswi MAN 2 Pekalongan berasal dari Kelurahan Medono,
Kelurahan Podo Sugih, Kelurahan Bendan Kecamatan Pekalongan Barat, Wilayah Kota Madya Pekalongan, Kabupaten Pekalongan, Wilayah Kabupaten Batang, Wilayah Kabupaten Pemalang, dan Wilayah Kabupaten Tegal.

Berdasarkan wawancara dengan (Bapak SY dan Bapak WM, tanggal 9 April 2014) setelah penerapan pendidikan humanis religius yaitu: (a) memberikan perhatian pada keunikan siswa; (b) suasana pembelajaran lebih kooperatif dan demokratis; (c) perusaha menciptakan hubungan pendidikan antara guru dan siswa dengan kepercayaan, memberikan pertumbuhan individu untuk mengembangkan kreatifitasnya dalam mengaktualisasikan diri, dan menjauhi hubungan yang merugikan seperti disiplin keras, ketakutan akan kegagalan serta lingkungan yang mengancam.

Berdasarkan wawancara dengan (Bapak SY dan Bapak PPS, tanggal 11 April 2014) penanaman pola berfikir siswa yang humanis religius, pola bersikap siswa yang humanis religius dan pola bertindak siswa yang humanis religius dapat terbentuk kepribadian humanis religius yang utuh sebagai berikut:

Nilai-nilai yang menjadi target atau tujuan pendidikan yang akan dicapai dalam pendidikan nilai humanis religius di MAN 2 Pekalongan yaitu: (1) nilai Iman; (2) ilmu agama; (3) ritualistik; (4) konsekuensi; (5) eksperiensial; (6) kebebasan; (7) bertanggung jawab; (8) kejujuran; (9) rasa aman; (10) kerja sama/saling menghargai; 11) aktualisasi diri/kreativitas; (12) Kejujuran (Sy, tanggal 8 April 2014).

Inti penggerak semua aktivitas adalah nilai iman. Iman menggerakkan dimensi-dimensi religius yang lain, serta religius yang terdiri dari lima dimensi tersebut, akan menjadi penggerak terhadap nilai humanis seperti kebebasan bertanggung jawab, kedisiplinan, kerja sama, kejujuran, rasa aman, serta kreativitas siswa.

Pendidikan humanis religius di MAN 2 Pekalongan telah dilakukan perbaikan, hal tersebut ditunjukkan dengan aspek-aspek di bawah ini: Pertama, guru dipandang sebagai faktor pendidikan yang sangat berpengaruh dalam membentuk karakter nilai humanis 
religius siswa. Guru berperan dalam kegiatan yang terangkum dalam kultur madrasah, yang meliputi kegiatan kepemimpinan, human relation, kegiatan intra kurikuler, ekstra kurikuler, bimbingan konseling, dan bimbingan ibadah. Penekanan kepada peran guru dalam pola pendidikan nilai humanis religius harus dilakukan. Pembahasan tentang guru dan siswa harus mendapat perhatian. Kedua, aspek kepemimpinan dalam kultur, bukan hanya kepemimpinan Kepala Madrasah sebagai penggerak kultur, tetapi juga kepemimpinan guru dalam mengelola siswa; baik di kelas maupun di luar kelas. Ketiga, dalam pengkondisian human relation, harus diperhatikan peran Tata Usaha dalam aspek pelayanan siswa, yakni pelayanan yang sejalan dengan konsep pendidikan humanis religius. Keempat, rendahnya aktualisasi nilai humanis religius ini harus dilihat pada aspek yang paling dominan menjadi penyebabnya. Apakah latar belakang keluarga, lingkungan pergaulan, atau lembaga sekolah itu sendiri. setelah diketahui, hal itu akan menjadi pemandu dalam memperbaikinya. Kelima, tentang nilai yang menjadi target dalam pendidikan humanis religius, nilai iman harus dijadikan titik tolak dari pendidikan humanis religius yang dilaksanakan. Nilai iman merupakan kesadaran awal sebagai inisiatif berbuat sesuai dengan ilmunya. Nilai iman merupakan penggerak awal dalam bertindak atau menahan untuk tidak bertindak. Nilai iman berefek kepada nilai kejujuran, tanggung jawab, sabar, berani, berkorban demi kepentingan yang lebih besar, serta menerima dengan lapang dada ketika rugi untuk meraih suatu tujuan yang lebih besar. Semua itu bergerak atas nilai iman. Keenam, konsep tarbiah, yakni pendidikan Islam, ditambahkan dalam kajian pustaka untuk memperkaya pendidikan nilai humanis religius dalam perspektif Islam. Ketujuh, penggunaan istilah kultur madrasah secara konsisten dilakukan, karena di madrasah mempunyai karakteristik kultur yang berbeda dengan sekolah pada umumnya (Sy, tanggal 27 Februari 2014).

Karakteristik pendidikan humanis religius memiliki ciri-ciri sebagai berikut: (a) penciptaan lingkungan pembelajaran yang para siswa terbebas dari persaingan intens, disiplin kaku, dan rasa takut akan kegagalan. (b) penciptaan lingkungan pembelajaran yang akrab antara pendidik dan subjek didik, sehingga tumbuh rasa aman dan tumbuh rasa keperca- yaan bagi subjek didik terhadap pendidiknya. Siswa terbebas dari rasa takut yang merusak dan memakan energi, yang semestinya dapat dikeluarkan untuk pertumbuhan dan perkembangan perorangan dalam mengembangkan kreativitas; (c) penciptaan lingkungan pembelajaran yang tidak mengekang (melampaui mentalitas bui), sehingga mengarah pada pertumbuhan perorangan dan aktualisasi diri yang lebih diutamakan, bukan pada penguasaan pengetahuan atau penumpukan ilmu pengetahuan; (d) para pendidik atau guru dapat menjangkau siswanya melalui kerja sama dengan orang-orang dan kelompok-kelompok kecil. Pada akar eksistensialnya, pendidikan humanis berusaha menghindari sekumpulan orientasi masyarakat modern (Sy, tanggal 2 Mei 2014).

Isi pendidikan nilai humanis religius mempunyai karakteristik antara lain, penanaman nilai religius atau keagamaan yang bersifat utuh atau tidak parsial. Penanaman nilai religius yang utuh meliputi lima dimensi keberagaman sebagai berikut: (a) usaha untuk memahamkan nilai-nilai agama secara keilmuan (religius knowledge); (b) menanamkan dan memfasilitasi tumbuhnya kepercayaan atau keimanan dalam agama (religius belief); (c) membimbing, memfasilitasi, serta menjadi teladan dalam praktek-praktek pengalaman agama (religius practice); (d) membimbing dan memfasilitasi tumbuhnya perasaan dan penghayatan keagamaan (religius feeling). (e). Membimbing dan memfasilitasi terwujudnya dampak keagamaan atau konsekuensi agama dalam segala aspek kehidupan (religius effects) (PS, tanggal 3 Mei 2014).

Dari proses pendidikan dengan isi dari nilai-nilai humanis religus tersebut, dapat terwujud siswa yang berkepribadian humanis religius.

Selain ibadah wajib, bimbingan juga perlu ditujukan pada ibadah-ibadah sunnah, seperti shalat rowatib, shalat dhuha, shalat malam (shalat tahajut), dan lain-lain. Ibadah sunnah itu lebih menuntut keikhlasan yang tinggi. Oleh karena itu bimbingan ikhlas ini harus dilakukan secara konsisten. Ikhlas mengarahkan seluruh amal perbuatan semata kepada Allah, bukan yang lain. Ikhlas menghadapkan seluruh amal perbuatan batiniah kepada Allah semata, demikian pula dengan amal perbuatan lahiriah. Shalat khusyu melahirkan kesehatan fisik dan psikis. Menjalan- 
kan shalat fajar maupun shalat malam, akan mudah seseorang mencapai keiklasan dan kekhusu'an. Kondisi ikhlas dan khusus, seseorang akan mengingat Allah SWT.

Pendidikan humanis religius melalui saluran kultur madrasah meliputi beberapa cara yaitu sebagai berikut. Pertama, membangun sistem kepemimpinan yang demokratis. Kepemimpinan yang dimaksud baik sistem yang dikondisikan kepala madrasah, maupun kepemimpinan guru dalam mengelola pembelajaran. Membangun kepemimpinan demokratis bagi organisasi-organisasi siswa yang ada di madrasah.

Kedua, membangun human relation di madrasah yang humanis religius. Wujud dari hal tersebut diantaranya penyambutan oleh para guru dengan: senyum, sapa, salam kepada para siswa ketika datang ke sekolah. Para guru dan kepala sekolah menyalami para siswa ketika datang ke sekolah. Hubungan antara guru dan murid diusahakan tidak ada kesenjangan, tetapi lebih pada hubungan interpersonal yang akrab tetapi tetap hormat.

Ketiga, kegiatan-kegiatan ekstrakurikuler dirancang, dilaksanakan dan dievaluasi oleh guru dan siswa, guru bertindak sebagai fasilitator. Guru bertindak sebagai pendamping, dan senior siswa. Keempat, Guru menciptakan iklim pembelajaran di kelas yang demokratis, tidak menekan dan tidak menakutkan siswa. Pengaturan ruangan dan tempat duduk siswa diatur bersama yaitu wali kelas dan siswa. Kelima, pembimbingan dan pendampingan ibadah, terutama ibadah pokok yakni shalat wajib. Shalat akan berpengaruh pada aspek-aspek lain dalam kehidupan. Di samping shalat mengandung dimensi-dimensi keberagaman secara utuh.

Keenam, Guru bimbingan konseling (BK) melakukan pelayanan kepada siswa sesuai dengan konsep pendidikan humanis religius. Siswa dihargai harkat dan martabatnya sebagai manusia dengan segala kekurangan dan kelebihannya. Bidang Bimbingan Konseling (BK) bukan polisi sekolah, tetapi tempat untuk berkonsultasi dan berfungsi membimbing karier siswa, konsultasi solusi dari permasalahan yang dihadapi siswa. Bimbingan Konseling juga melakukan audiensi dengan orang tua siswa, terutama bagi siswa yang bermasalah untuk melihat pengaruh keluarga maupun teman sepergaulan. Ketujuh, Kepala TU menyediakan sarana pendukung yang menyangkut penyediaan sarana prasarana yang berkaitan dengan kegiatan-kegiatan pendidikan melalui saluran kultur pendidikan humanis religius (Sy, tanggal 7 April 2014).

\section{Simpulan dan Saran}

Simpulan

Perilaku siswa sebelum dilakukan perbaikan kultur madrasah adalah: aktualisasi nilai humanis religius para siswa di Madrasah Aliyah Negeri 2 Pekalongan kurang sempurna. Hal tersebut ditunjukkan adanya beberapa hal sebagai berikut. Pertama, dimensi iman siswa belum berfungsi sebagai penggerak aktivitas secara maksimal, serta belum utuh keberagamannya, aktualisasi nilai humanis yang muncul pada diri siswa hanya ketika dalam kondisi normal yaitu sewaktu siswa tidak menghadapi masalah dan tidak ada sangsi. Ketika siswa terdesak kebutuhan dan kepentingan pribadi dan tidak siap solusi, para siswa tersebut cenderung melanggar nilai-nilai humanis seperti mencontek. Kedua, pendidikan yang memberiakan kebebasan siswa dalam beraktualisasi diri, menjadikan sikap peserta didik lebih terbuka dan dekat dengan pendidik, kreatif serta berprestasi dalam bidang yang ditekuni. Hal ini membuka peluang bagi pendidik untuk melakukan pendampingan dalam mencapai tujuan pendidikan yang lebih optimal.

Karakteristik religius siswa yang tidak utuh, yakni baru sebatas dimensi ritual dan dimensi ilmu. Dimensi iman, eksperimental, dan konsekuensial belum menyatu utuh dalam diri siswa. Dimensi iman meliputi keyakinan terhadap akidah Islam, dimensi eksperimental meliputi perasaan keagamaan seseorang setelah menjalankan perintah Allah, dimensi konsekuensial meliputi akhlak yang mulia. Pendidikan nilai humanis religius berbasis kultur yang dilaksanakan di Madrasah Aliyah Negeri 2 Pekalongan sebelum penerapan masih sebatas pada pola pendidikan konvensional yakni: (a) cara membangun aktualisasi nilai humanis religius, masih sebatas pada kegiatan intrakurikuler, yakni pembelajaran Pendidikan Agama Islam di kelas, dan ekstrakurikuler seperti shalat berjama'ah, kultum, atau pengajian secara tempora/pesantren kilat, sedangkan aspek-aspek kultur yang lain belum diberdayakan secara maksimal; (b) pemaksaan dalam pembelajaran dengan banyak 
hukuman dan sangsi-sangsi, telah menimbulkan dendam peserta didik kepada guru, yang berakibat potensi yang ada tidak bisa berkembang secara optimal.

Pendidikan nilai humanis religius pada diri siswa berbasis kultur madrasah, dilakukan dengan beberapa tahapyaitu sebagai berikut. Pertama, menggambarkan kultur Madrasah. Kegiatan ini meliputi; menggambarkan kultur madrasah, menganalisis, serta memberikan makna gambaran kultur madrasah, yang meliputi material culture dan behavioral culture, yang pada akhirnya ditemukan kultur positif dan negatif. Kedua, penentuan Visi dan Misi Madrasah. Berdasarkan kondisi riil potret kultur madrasah, ditentukan visi menuju kondisi yang diidealkan yakni "madrasah religius, unggul dan berprestasi". Misinya adalah: (1) terselenggaranya pendidikan yang berkualitas di bidang pendidikan agama dan umum; (2) terlaksananya dan terwujudnya prestasi unggul dalam program pengembangan diri dan ketrampilan; (3) mengamalkan dan mengembangkan nilai-nilai agama Islam dan mengembangkan sifat keagamaan dalam kehidupan bermasyarakat; (4) mengembangkan budaya kreatif dan kompetitif dalam upaya pencapaian dan peningkatan prestasi; (c) pendidikan nilai humanis religius diimplementasikan melalui saluran kultur madrasah yang meliputi: (1) sistem kepemimpinan kultur kepala madrasah, guru dan tata usaha, (2) model human relation yang humanis religius. (3) peran guru dan siswa dalam kegiatan intrakurikuler dan ekstrakurikuler, (4) pelayanan bimbingan konseling yang humanis religius, (5) format kegiatan bimbingan ibadah yang komprehensif, serta audiensi dengan orang tua atau tokoh masyarakat.

Saran

Penelitian ini dalam bidang nilai-nilai humanis religius siswa. Sebagaimana disadari bahwa, pengukuran terhadap aktualisasi nilai merupakan suatu hal yang tidak mudah dilakukan. Demikian juga pendidikan nilai, merupakan pendidikan jangka panjang yang hasilnya tidak bisa segera dirasakan.

Penelitian dilakukan di wilayah Pekalongan yang mempunyai karakteristik homogen dalam bidang sosio-kultural dan religius. Bagi wilayah yang mempunyai sosio-kultural-religius dengan heterogenitas tinggi, diperlukan juga pendidikan yang berbeda.
Pendidikan berbasis kultur madrasah ini akan efektif apabila kepala Madrasah beserta stafnya bisa mengendalikan kebijakan madrasah. Hal tersebut karena kultur menyangkut banyak aspek, yang harus digerakkan dengan tipe kepemimpinan yang bisa memberdayakan segala komponen.

Memahamkan subjek didik dalam hal nilai-nilai bukan hal yang mudah. Hal tersebut karena para guru/orang tua hidup dan dididik dalam konteks masa lalu. Sedangkan yang dihadapi, adalah para siswa yang hidup dalam konteks kekinian, para peserta didik sangat mungkin mempunyai paradigma yang berbeda dengan paradigma guru/orang tua. Di sinilah diperlukan dialog antara guru/orang tua dengan peserta didik.

\section{Daftar Pustaka}

Arief Armai dkk. (2011). Pendidikan humanistik: konsep, teori, dan aplikasi praksis dalam dunia pendidikan. Yogyakarta: AR-RUZZ MEDIA.

Al-Fandi Haryanto. (2011). Desain pembelajaran yang demokratis dan humanis. Yogyakarta: AR-RUZZ MEDIA.

Bungin Burhan. (2012). Analisis data penelitian kualitatif. Jakarta: Raja Grafindo Persada.

Dardiri Achmad. (2010). Revitalisasi fungsi pendidikan untuk mewujudkan pendidikan yang humanis-religius. Yogyakarta: Universitas Negeri Yogyakarta.

Huberman dan Miles. (1992). Analisis data kualitatif. Jakarta: Universitas Indonesia Press.

Moleong, LJ. (2013). Metodologi penelitian kualitatif. Bandung: Remaja Rosda Karya.

Nawawi, Hadari. (2012). Metode penelitian sosial. Yogyakarta: Gadjah Mada University Press.

Sudarwan, Danim. (2002). Menjadi peneliti kualitatif: ancangan metodologi, presentasi, dan publikasi hasil penelitian untuk mahasiswa dan peneliti pemula bidang ilmu-ilmu sosial, pendidikan dan humaniora. Bandung: CV. Pustaka Setia.

Usman, Husaini, dkk. (2011). Metodologi penelitian sosial. Jakarta: Bumi Aksara. 